\title{
OPTIMIZATION OF BIOFLOCCULANT PRODUCTION BY BACTERIA ISOLATED FROM OIL-POLLUTED SOIL AND FERMENTED MAIZE EFFLUENT
}

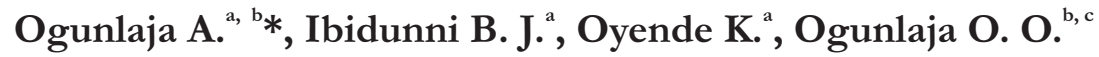 \\ ${ }^{2}$ Department of Biological Sciences, Redeemer's University, Ede, Osun State, Nigeria. \\ ${ }^{b}$ Africa Centre of Excellence for Water and Environmental Research, Redeemer's University, Ede, Osun State, Nigeria. \\ 'Department of Chemical Sciences, Lead City University, Ibadan. \\ E-mail for correspondence: ogunlajaa@run.edu.ng \\ (Received: $24^{\text {th }}$ October, 2019; Accepted: $31^{\text {st }}$ March, 2020)
}

\section{ABSTRACT}

\begin{abstract}
This study involved isolation of bioflocculant producing bacteria from soil and waste water. The isolates were tested for flocculation activities and those deemed fit were identified and the optimal environmental conditions for bioflocculant production were also determined. Samples were collected from oil-contaminated soil in Redeemer's University and fermented maize waste water. Microbial isolation was done using standard microbiological methods and identification was done using morphology, biochemical and molecular method with universal primer for 16SrRNA gene. Environmental conditions ( $\mathrm{pH}$, Temperature and cations) and media composition (nitrogen and carbon sources) were altered to optimize bioflocculant production and activities. Percentage flocculating activities were determined and calculated using standard method. We also adjusted revolution rate and standing time to determine the optimum conditions for flocculation activities. Two bioflocculant producing isolates (Bacillus cereus and Lysinibacillus fusiformis) from oil-polluted soil and two from fermented maize waste water (Bacillus thuringiensis and Bacillus tropicus) were obtained. Neutral $\mathrm{pH}$, temperature of $30^{\circ} \mathrm{C}$ and inclusion of $\mathrm{CaCl}_{2}$ were the best conditions for bioflocculant production in all isolates except for Lysinibacillus fusiformis which was best with acidic $\mathrm{pH}$ condition. Maltose as the carbon source was the best for all isolates except Bacillus thuringiensis (fructose) and ammonium was the best nitrogen source for all isolates except Bacillus cereus (peptone). Although condition III showed optimum condition for flocculation activities, the percentage activities were generally lower than normal condition. The highest percentage flocculating activities of $98 \%$ were by Bacillus cereus and Bacillus tropicus at $30^{\circ} \mathrm{C}$, neutral $\mathrm{pH}$ and $1 \%\left(\mathrm{w} / \mathrm{v}\right.$ ) $\mathrm{CaCl}_{2}$ salt with soluble starch and maltose as their carbon source respectively. These bacteria can be exploited for their use as flocculants in water treatment.
\end{abstract}

Keywords: Agro-residues; Bio-friendly; Bioflocculant; Contaminated soil; Optimization

\section{INTRODUCTION}

Water is an abundant resource in nature (Gbaruko et al., 2008) but useable water is inadequate. Treatment of water is of necessity in order to achieve the quality of water needed for particular uses. Flocculation, among other types of treatment procedures, is a necessary phase in water treatment in which insoluble and suspended substances are removed by using flocculants. Flocs of these insoluble substances settle down resulting in the clarity of the water. The commonest flocculants used in water treatments are synthetic chemical agents of inorganic and organic origin; they are efficient, economical and readily available. However, health and environmental concerns are raised as investigations have incriminated most chemical flocculants as disease causing agents (Salehizadeh and Shojaosadati, 2001; Zhou et al., 2017).
Treatment of water for food processing, biotechnological processes, portable water production and wastewater treatment (Seo et al., 1997; Zhang et al., 1998; Salehzadeh and Shojaosadati, 2001) are common industrial procedures which involve the use of flocculation / coagulation. Production of portable water for example involves the use of chemical flocculants such as polyaluminum chloride (PAC) and aluminum sulfate (AS) because they are cheap and efficient. However, aluminium has been incriminated with Alzheimer and Parkinson diseases (Polizzi et al., 2002). Polyacrylamide and aluminium have been reported as neurotoxic and carcinogenic agents (Salehizadeh and Shojaosadati, 2001; Shih and Van, 2001). These challenges make it imperative for safer alternatives to be sourced hence the ongoing search for flocculating agents such as bioflocculants. Bioflocculants have no known health risk, they are 
biodegradable and are environmentally friendly thus their use have attained a very huge biotechnological attention recently (Zaki et al., 2013).

Bioflocculants are natural flocculants having a plant, animal or microbial origin. They may be composed of polysaccharide, proteins, lipids, lipoproteins and lipopolysaccharides; flocculation by them involves the polymer chain sticking to multiple particles making an aggregate large enough to settle down. Several groups of microorganisms such as algae, bacteria, actinomycetes and fungi, have been reported to produce bioflocculants (Takagi and Kadowaki, 1985; Zhang et al., 1998; Huang et al., 2014). Microbes, especially bacteria are versatile, have shorter generation time and can produce these extracellular polymeric materials. The commonest bacteria reported to secrete biopolymer flocculants are Bacillus sp (Suh et al., 1997; Salehizadeh and Shojaosadati, 2001; Deng et al., 2003). Although bioflocculants are exploited industrially, their relative poor efficiency and large dosage of inoculants is a big challenge (Gao et al., 2006). Carbon sources, nitrogen sources, hydraulic conditions and sedimentation time are influencing parameters that affect bioflocculant production and activities. Identifying thermostable bioflocculant producing organisms from various sites and enhancing conditions for bioflocculation efficiency / yield has therefore become apparent. Hence, optimization of bioflocculant production by manipulating factors to achieve low cost industrial use remains an ongoing search. This study was aimed at isolating and identifying bioflocculant producing aerobic bacteria from petroleum-polluted soil and fermented maize (ogi) waste water and determining the optimized conditions for flocculation activities of the bioflocculants produced.

\section{MATERIALS AND METHODS \\ Sample Collection and Preparation}

One hundred grams of soil samples were collected from diesel contaminated site within Redeemer's University Campus (near ACEGID generator stand) into labelled sterile containers (K) and transported to the laboratory. Also, $50 \mathrm{ml}$ of fermented maize (og $\imath$ effluent sample was collected in sterile sample bottles (J). All samples were collected in triplicates

\section{Screening for Bioflocculant producing Bacteria from Diesel- Contaminated soil and Fermented Maize (ogi) Effluent at Various Temperatures}

Five (5) grams of each soil sample was suspended in $45 \mathrm{ml}$ of sterile distilled water, stirred for 30 minutes and aliquot of $1 \mathrm{ml}$ was centrifuged at 400 $\mathrm{rpm}$ for $1 \mathrm{~min}$ in a table top micro centrifuge (Beckman Coulter, 368826 model). The resulting supernatant from the soil samples and $1 \mathrm{ml}$ of the fermented maize effluent were serially diluted separately in sterile distilled water up to $10^{-7}$ and $100 \mu \mathrm{l}$ of each diluents was spread on selective isolation media $(20 \mathrm{~g} / \mathrm{L}$ soluble starch, $1 \mathrm{~g} / \mathrm{L}$ $\mathrm{KNO}_{3}, 0.5 \mathrm{~g} / \mathrm{L} \mathrm{MgSO}{ }_{4} \cdot 7 \mathrm{H}_{2} \mathrm{O}, 0.5 \mathrm{~g} / \mathrm{L} \mathrm{NaCl}, 0.5$ $\mathrm{g} / \mathrm{L} \mathrm{K}_{2} \mathrm{HPO}_{4} \cdot 3 \mathrm{H}_{2} \mathrm{O}$, and $15-20 \mathrm{~g} / \mathrm{L}$ agar powder). The agar plates were incubated at different temperatures, $20{ }^{\circ} \mathrm{C}, 30{ }^{\circ} \mathrm{C}, 33{ }^{\circ} \mathrm{C}$ and $37{ }^{\circ} \mathrm{C}$ respectively for 5 days. Colonies with distinct morphological characteristics were sub cultured into nutrient agar plate with sterile wire loop and incubated at $20{ }^{\circ} \mathrm{C}, 30{ }^{\circ} \mathrm{C}, 33{ }^{\circ} \mathrm{C}$ and $37{ }^{\circ} \mathrm{C}$ respectively for $24 \mathrm{~h}$ to obtain pure culture. Pure isolates were then sub cultured into $50 \mathrm{ml}$ of nutrient broth and incubated at $20^{\circ} \mathrm{C}, 30^{\circ} \mathrm{C}, 33^{\circ} \mathrm{C}$ and $37^{\circ} \mathrm{C}$, respectively for 3 days. The flocculating activity of each pure isolate was determined according to the method of Abd-El-Haleem et al. (2008). Isolates with flocculating activities of $\geqslant$ $50 \%$ were preserved on nutrient agar slants in Bijou bottles with labels KA, KB, JA and JB. They were stored at $4{ }^{\circ} \mathrm{C}$ in the refrigerator for further experiments.

\section{Determination of Flocculating Activity}

The broth culture of the isolates were centrifuged (Beckman Coulter, 368826 model) at $3000 \mathrm{rpm}$ for $1 \mathrm{~min}$ and the supernatant collected for flocculating activities as previously described by Abd-El-Haleem et al. (2008). Briefly, Kaolin clay (5 $\mathrm{g} / \mathrm{L}$ ) was used as the solid phase in suspension and $100 \mathrm{ml}$ of the suspension was used for each experiment in a conical flask. The $\mathrm{pH}$ was adjusted to 7.0 and $6 \mathrm{ml}$ of $1 \%(\mathrm{~m} / \mathrm{v}) \mathrm{CaCl}_{2}$ added to the conical flask. $2 \mathrm{ml}$ of the cell free supernatant from broth culture of each isolate was added and then swirled for $1 \mathrm{~min}$ and allowed to settle for 5 
min. The absorbance of triplicate samples and control were measured at $550 \mathrm{~nm}$ in a spectrophotometer (JP Selecta, SA) and used to calculate the $\%$ percentage flocculation activity and their mean values were determined (Abd-ElHaleem et al., 2008).

Percentage flocculation activity was calculated with the formula:

$\%$ Flocculating rate $=\mathrm{A}-\mathrm{B}$

$$
\begin{gathered}
\frac{\mathrm{A}}{\mathrm{A}} \times 100 \% \\
\mathrm{~A}=\text { absorbance of control } \\
\mathrm{B}=\text { absorbance of sample }
\end{gathered}
$$

Morphological Characterization and Biochemical Identification of Bioflocculant Producing Isolates

Isolates from the selective isolation media $(20 \mathrm{~g} / \mathrm{L}$ soluble starch, $1 \mathrm{~g} / \mathrm{L} \quad \mathrm{KNO}_{3}, 0.5 \mathrm{~g} / \mathrm{L}$ $\mathrm{MgSO}_{4} .7 \mathrm{H}_{2} \mathrm{O}, 0.5 \mathrm{~g} / \mathrm{L} \quad \mathrm{NaCl}, 0.5 \mathrm{~g} / \mathrm{L}$ $\mathrm{K}_{2} \mathrm{HPO}_{4} \cdot 3 \mathrm{H}_{2} \mathrm{O}$, and $15-20 \mathrm{~g} / \mathrm{L}$ agar powder) that showed $\geqslant 50 \%$ flocculation rate were subjected to Gram staining after which morphological characterization was done. Other biochemical tests were carried out to further identify the bioflocculant producing isolates.

DNA Extraction and Identification of Bioflocculant Producing Isolate

Pure colonies of the isolates with bioflocculation activities of $\geq 50 \%$ were also sub cultured into sterile nutrient broth and incubated at $30^{\circ} \mathrm{C}$ for 24 h. Aliquot of the isolates were used for DNA extraction with DNA extraction kit (ZYMO RESEARCH) according to the manufacturer's instruction. The concentration and quality of the extracted cellular DNA was assessed using a Nanodrop spectrophotometer and their fitness for further downstream molecular analyses was ascertained.

DNA extracts were amplified targeting 16SrRNA gene for molecular identification. DNA amplification involved using a final volume of 20 $\mu \mathrm{l}$ with $2 \mu \mathrm{l}$ of DNA extract; each mixture consisted of $10 \mu \mathrm{l}$ Phusion High-Fidelity PCR Master mix (Thermo Fisher Scientific), $4 \mu \mathrm{l}$ of sterile double distilled water $\left(\mathrm{ddH}_{2} \mathrm{O}\right)$, and $2 \mu \mathrm{l}(10$ $\mathrm{mM}$ ) universal primers for $16 \mathrm{~S}$ rRNA genes; $27 \mathrm{~F}$ and 1492R.The PCR amplification was done using the following conditions: one cycle of $3 \mathrm{~min}$ at 95 ${ }^{\circ} \mathrm{C} ; 24$ cycles of $10 \mathrm{~s}$ at $95^{\circ} \mathrm{C}, 10 \mathrm{~s}$ at $50{ }^{\circ} \mathrm{C}, 1 \mathrm{~min}$ at $72{ }^{\circ} \mathrm{C}$; and one cycle at $72{ }^{\circ} \mathrm{C}$ for $5 \mathrm{~min}$ with modification (Lane, 1991).

Each reaction product was cloned by standard ligation process using PJet2.1 vector (Thermo Fisher, Scientific) and ligase (Thermo Fisher, Scientific). Transformation into $\mathrm{DH} 4 \alpha$ competent cells was done and cultured on nutrient agar (ampicillin enriched) overnight for further colony PCR process (same as the PCR condition above). Confirmation of positive insert was done by resolving the PCR product with electrophoresis on $1 \%(\mathrm{w} / \mathrm{v})$ agarose gel with ethidium bromide stain. Positive colonies were inoculated into $5 \mathrm{ml}$ sterile ampicillin enriched nutrient broth. Plasmid isolation was carried out on each isolate with Genejet plasmid kit (Thermo Fischer, Scientific) by following the manufacturer's instruction. Digestion and gel electrophoresis was done to confirm successful clones. Sequencing of plasmids in both directions was done using BigDye ${ }^{\circledR}$ Terminator Cycle Sequencing Kit (Thermo Fisher) following the manufacturer's protocol. The nucleotide sequences for the 16SrRNA of the bacterial isolates (JA, JB, KA and $\mathrm{KB}$ ) were compared with other bacteria nucleotide sequences using NCBI BLAST tool (Madden, 2013).

\section{Effect of $\mathrm{pH}$ on Flocculating activity of Bacterial Isolates}

Using pre-determined optimum temperature of $30{ }^{\circ} \mathrm{C}$ and other culture conditions mentioned previously (in this study), the $\mathrm{pH}$ of kaolin suspension was adjusted in each flasks ranging from $\mathrm{pH} 4-9.5$ with either $\mathrm{NaOH}(0.1 \mathrm{M})$ or $\mathrm{HCl}$ $(0.1 \mathrm{M})$ and the flocculating activity was determined as previously described above (AbdEl-Haleem et al., 2008).

\section{Effect of Cations on Flocculating Activities of Bacterial Isolates}

The influence of cations on flocculating activity of the bacterial isolates was determined at $30{ }^{\circ} \mathrm{C}$ and other culture conditions as mentioned 
previously except that $\mathrm{CaCl}_{2}$ was substituted with solutions of $\mathrm{KCl}$ and $\mathrm{AlCl}_{3}$ at $1 \% \mathrm{w} / \mathrm{v}$ concentration in the prepared selective isolation media. The flocculating activities of isolates were determined as elaborated above (Abd-El-Haleem et al., 2008).

\section{Determination of Optimal Culture Conditions and Orthogonal test for Turbidity Removal}

Based on preliminary optimum incubation temperature, $\mathrm{pH}$ and cation for flocculation testing earlier obtained, carbon sources (glucose, fructose and maltose) and nitrogen sources (ammonium, urea and peptone) in the production medium were substituted with one another to determine the effect of the various nutrient sources. Also, hydraulic condition like the revolution rate and standing time for settling were adjusted during flocculation activity tests to determine the optimal condition for bioflocculation activity. The three conditions involved revolution rate of $40 \mathrm{rpm}$ and settling time of $280 \mathrm{~s}$ as condition I (40 rpm/280 s), revolution rate of $160 \mathrm{rpm}$ and settling time of $280 \mathrm{~s}$ as condition II (160 rpm/280 s) and condition I followed by condition II as condition III $(40 \mathrm{rpm} / 280 \mathrm{~s}$ then $160 \mathrm{rpm} / 280 \mathrm{~s})$.

\section{Data analysis}

The mean and standard deviation were determined statistically using Graphpad Prism (8.0) package. The significant difference was at $\mathrm{P}<0.05$.

\section{RESULTS}

Bacterial Isolates from Diesel-Contaminated Site and Fermented Maize Effluent

There were four bioflocculant producing isolates from both soil and wastewater samples $(\mathrm{KA} / \mathrm{KB}$ and JA /JB) respectively. Their morphological characteristics and biochemical identification results are presented in table 1 below.

\section{Molecular Identification of Bioflocculant Producing Bacteria Isolates}

The closest $\%$ identity and $\%$ query cover among bacteria in the NCBI GenBank for 16SrRNA nucleotide sequences of the bioflocculant producing isolates are shown in table 2.

Table 1: Morphological and Biochemical Identity of Bacterial Isolates

\begin{tabular}{|c|c|c|c|c|c|c|c|c|c|c|c|c|c|c|}
\hline & 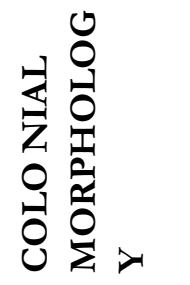 & $\sum_{\infty}^{\frac{1}{4}}$ & $\begin{array}{l}\frac{1}{5} \\
0 \\
0 \\
0 \\
0\end{array}$ & 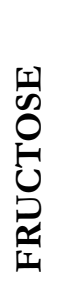 & $\begin{array}{l}\frac{1}{5} \\
0 \\
1 \\
\sum \\
\sum\end{array}$ & \begin{tabular}{l}
$\frac{1}{n}$ \\
0 \\
0 \\
0 \\
\hdashline
\end{tabular} & $\begin{array}{l}0 \\
0 \\
\frac{1}{Z} \\
\frac{1}{2}\end{array}$ & 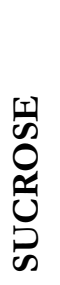 & 孚 & 音 & 岳 & 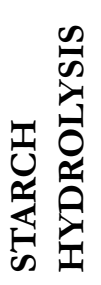 & 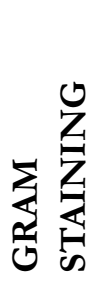 & 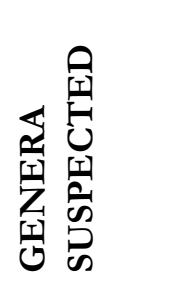 \\
\hline $\mathrm{KA}$ & $\begin{array}{l}\text { Circular } \\
\text { Creamy } \\
\text { Convex } \\
\text { Entire }\end{array}$ & Rod & + & + & + & - & - & - & + & - & + & + & + & Bacillus spp. \\
\hline KB & $\begin{array}{l}\text { Punctiform } \\
\text { Creamy } \\
\text { F lat } \\
\text { Rough }\end{array}$ & Rod & + & + & + & - & + & + & + & + & + & + & + & $\begin{array}{l}\text { Lysinibacillus } \\
\text { spp. }\end{array}$ \\
\hline JA & $\begin{array}{l}\text { Irregular } \\
\text { Creamy } \\
\text { Flat } \\
\text { Undulate }\end{array}$ & Rod & + & + & + & + & + & + & + & + & + & + & + & Bacillus spp. \\
\hline JB & $\begin{array}{l}\text { Creamy } \\
\text { Raised } \\
\text { Entire }\end{array}$ & Rod & + & + & + & + & + & + & + & + & + & + & + & Bacillus spp. \\
\hline
\end{tabular}


Table 2 Molecular Identity of Bioflocculant producing isolates

\begin{tabular}{lllll}
\hline $\begin{array}{l}\text { Isolate } \\
\text { codes }\end{array}$ & $\begin{array}{l}\text { Sequence } \\
\text { (Ascension No.) }\end{array}$ & \% Query Cover & \% Identity & Isolates Identified \\
\hline KA & NR112630.1 & 97 & 90.63 & Bacillus cereus \\
KB & MK574987.1 & 99 & 98.01 & Lysinibacillus fusiformis \\
JA & MK026873.1 & 99 & 97.92 & Bacillus thuringiensis \\
JB & CP041071.1 & 98 & 98.34 & Bacillus tro picus \\
\hline
\end{tabular}

Effect of incubation Temperature on Bioflocculation Activities of Bacterial Isolates

The percentage flocculation activities of Bacillus cereus, Bacillus thuringiensis and Bacillus tropicus were best at $30^{\circ} \mathrm{C}$ followed by $20^{\circ} \mathrm{C}$ followed by $33^{\circ} \mathrm{C}$ followed by $37{ }^{\circ} \mathrm{C}$ but Lysinibacillus fusiformis showed best flocculation activity at $30^{\circ} \mathrm{C}$ followed by $37{ }^{\circ} \mathrm{C}$ followed by $20^{\circ} \mathrm{C}$ followed by $33{ }^{\circ} \mathrm{C}$ (Figure 1). All isolates showed flocculation activities higher than $50 \%$ at $30^{\circ} \mathrm{C}$ hence $30^{\circ} \mathrm{C}$ was chosen as the optimum temperature and used for other optimization experiments. There were significant differences between the effect of incubation temperatures at $30{ }^{\circ} \mathrm{C}$ and $33{ }^{\circ} \mathrm{C}$ $(\mathrm{P}=0.03)$ and at $30^{\circ} \mathrm{C}$ and $37^{\circ} \mathrm{C}(\mathrm{P}=0.001)$.

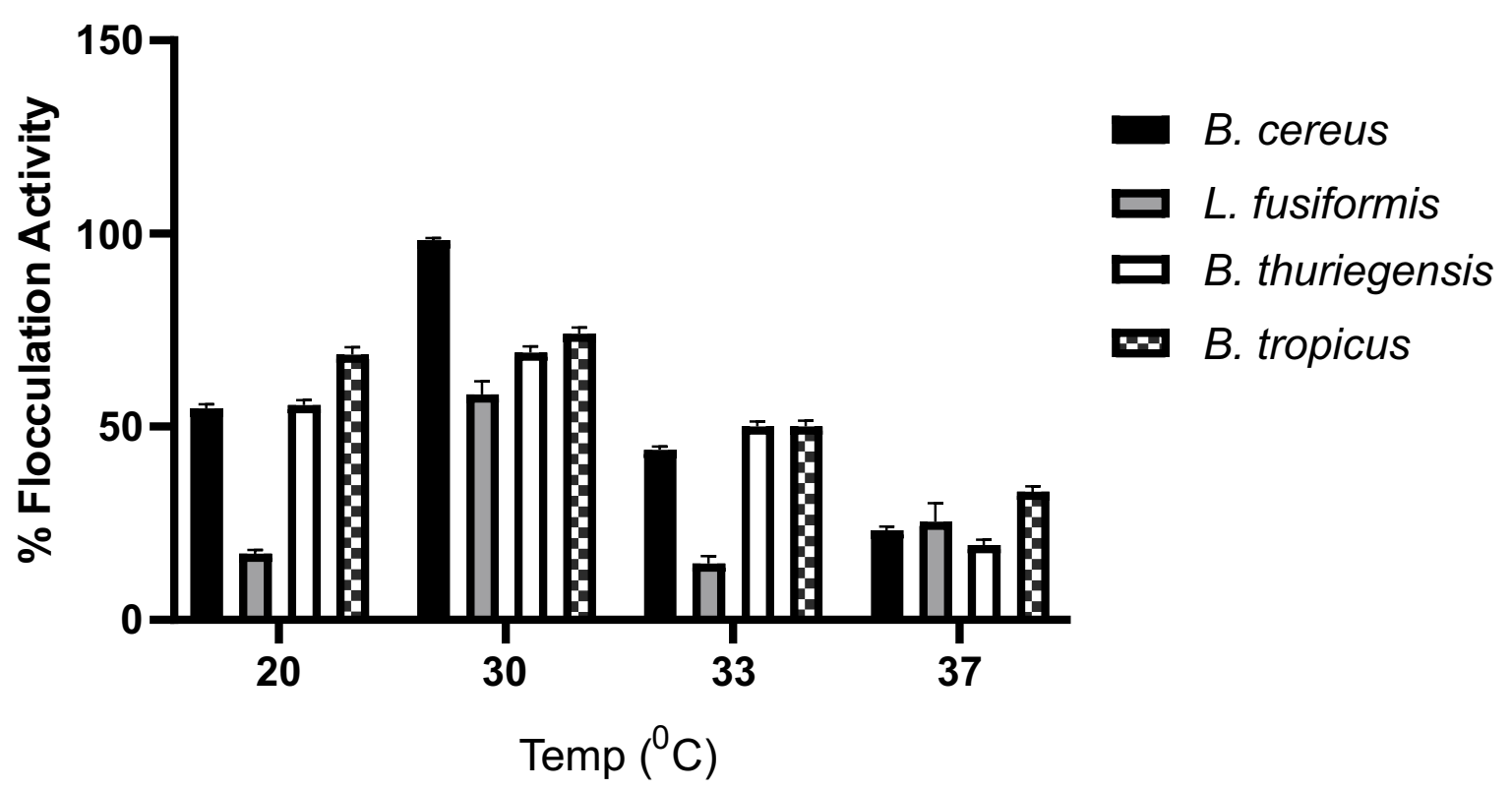

Figure 1: Average Percentage Flocculation Activities of Bacterial Isolates at Various Temperatures

Effect of $\mathrm{pH}$ on Bioflocculation Activities of Bacterial Isolates

The average percentage flocculation activities of all isolates (Bacillus cereus, Bacillus thuringiensis and Bacillus tropicus) were best at neutral pH (55 $\pm 4 \%$, $69 \pm 2 \%$ and $74 \pm 4 \%$, respectively) except for
Lysinibacillus fusiformis with its best activity at acidic $\mathrm{pH}(54 \pm 3 \%$ ) (Figure 2). Neutral $\mathrm{pH}$ was chosen as the optimum $\mathrm{pH}$ and was used for other optimization experiments. There were no significant differences in the effect of incubation $\mathrm{pH}$ on the activities of isolates $(\mathrm{P}=0.88)$ 


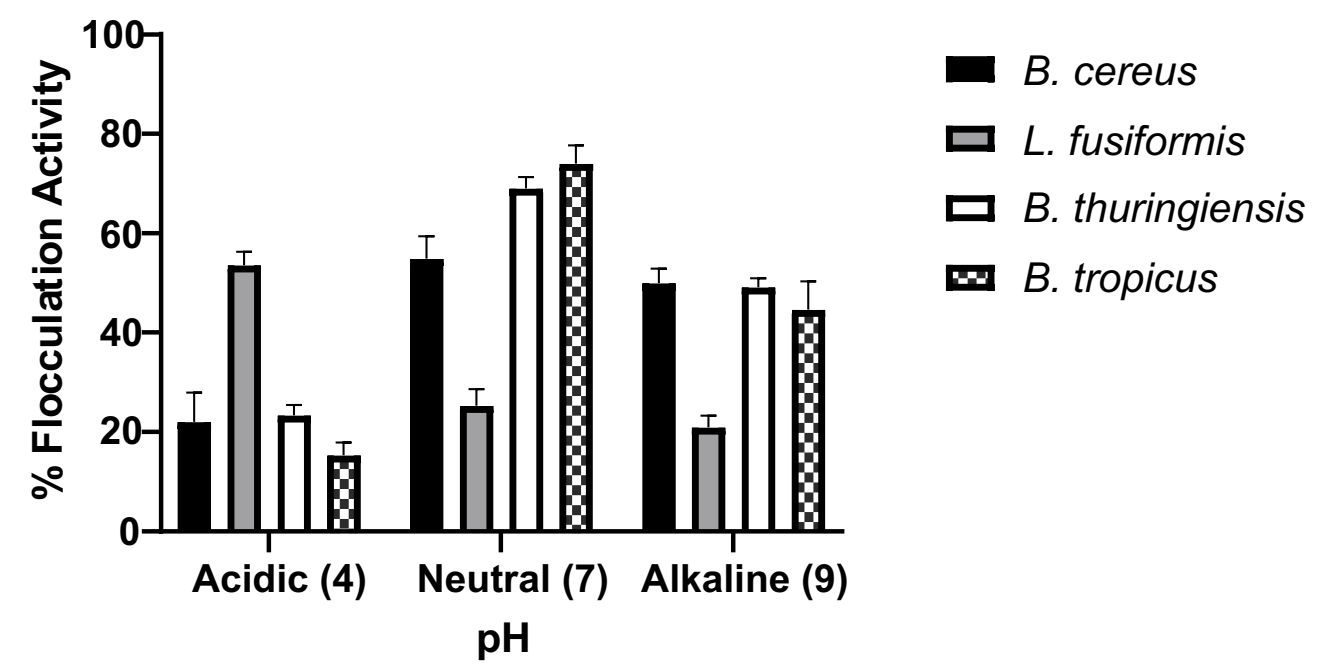

Figure 2: Percentage Flocculation Activities of Bacterial Isolates under Various pH Conditions

Effect of Cations on Bioflocculation Activities of Bacterial Isolates

The percentage flocculation activities ranged from $52 \%$ to $97 \%$ for all isolates and were best with $\mathrm{CaCl}_{2}$. This was followed by $\mathrm{AlCl}_{3}$ and then $\mathrm{KCl}$ for Bacillus cereus ( $44 \pm 4 \%$ and $32 \pm 4 \%$, respectively) and Lysinibacillus fusiformis (48 $\pm 3 \%$ and $12 \pm 2 \%$, respectively). However, the flocculation activities of Bacillus thuringiensis and Bacillus tropicus with $\mathrm{KCl}$ were followed by $\mathrm{AlCl}_{3}$.
For Bacillus thuringiensis the flocculation activities for $\mathrm{KCl}$ and $\mathrm{AlCl}_{3}$ were $34 \pm 1 \%$ and $20 \pm 3 \%$, respectively and Bacillus tropicus $23 \pm 1 \%$ and $10 \pm$ $3 \%$, respectively, as shown in figure $3 . \mathrm{CaCl}_{2}$ was chosen as the best salt and was used for other optimization experiments. There were significant differences between the effect of $\mathrm{CaCl}_{2}$ and $\mathrm{KCl}$ $(\mathrm{P}=0.002)$ and between the effect of $\mathrm{CaCl}_{2}$ and $\mathrm{AlCl}_{3}(\mathrm{P}=0.01)$ on the activities of the isolates.

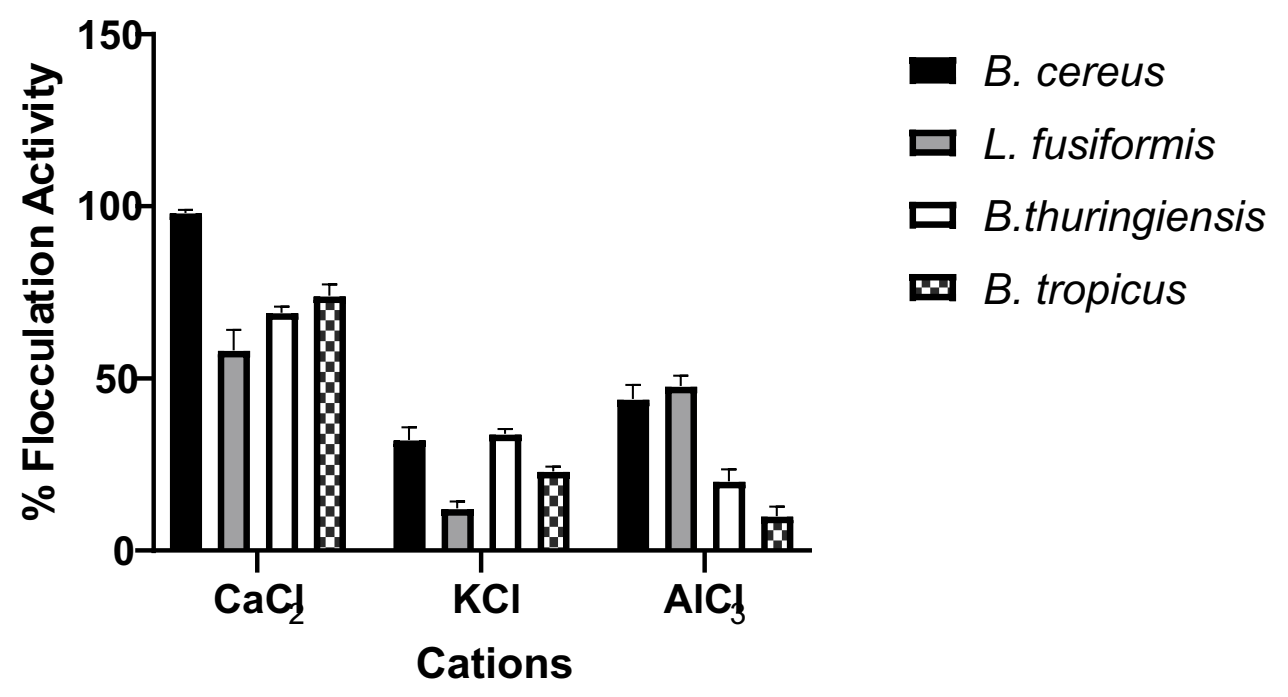

Figure 3: Average Percentage Flocculation Activities of Bacterial Isolates with Various Cations

Effect of Carbon Sources on Flocculation Activities of Bacteria Isolates

The flocculation activities of the bacterial isolates varied based on the carbon sources in their culture media. Bacillus cereus, Lysinibacillus fusiformis and Bacillus tropicus exhibited the highest flocculation activities in maltose enriched culture media (with ranges: $84-86 \%, 93-97 \%$ and $96-98 \%$, respectively) followed by glucose-substituted culture medium with ranges: $76-82 \%, 92-96 \%$ and $97-99 \%$, respectively. Among these isolates, Bacillus tropicus exhibited the best average 
flocculation activity $(98 \pm 1 \%$ ) with maltose as carbon source (Figure 4). Fructose-substituted culture medium was the least effective culture medium except in the case of Bacillus thuringiensis.
There were no significant differences in the effect of carbon sources on the isolate activities $(\mathrm{P}=$ $0.16)$.

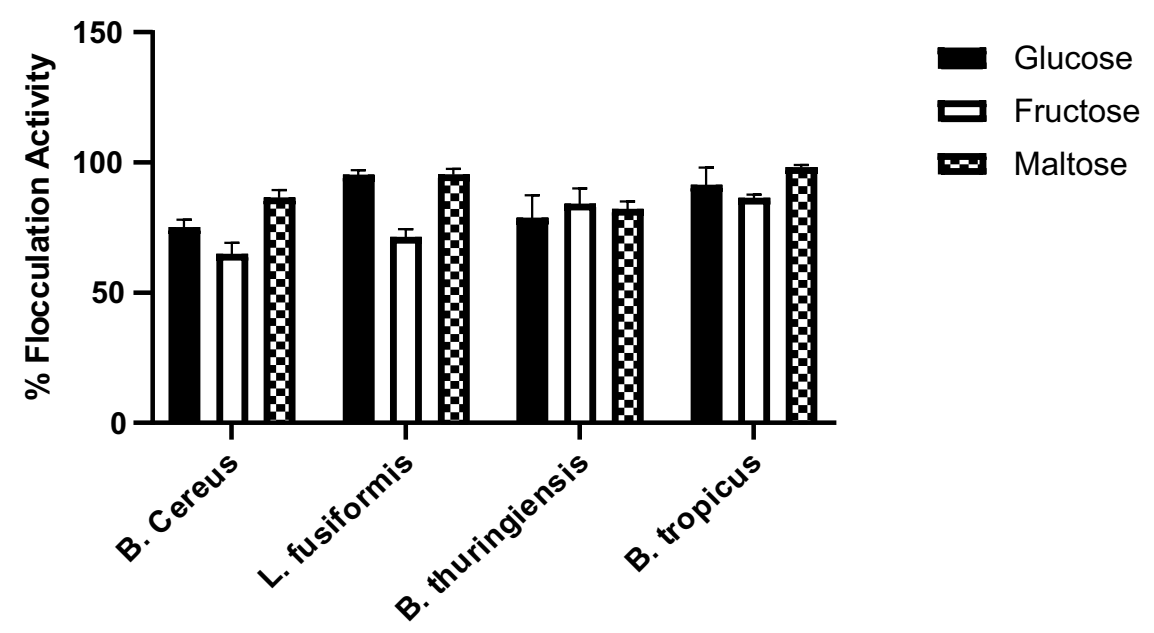

Figure 4: Percentage Flocculation Activities of Bacteria Isolates based on Carbon Sources

Effect of Nitrogen Sources on Flocculation Activities of Bacteria Isolates

Bacterial isolates showed varied flocculation activities based on their nitrogen sources. Bacillus tropicus exhibited the highest flocculation activities in ammonium $(91 \pm 5 \%)$ and urea $(90 \pm 2 \%)$ substituted culture, followed by Bacillus cereus ( $86 \pm$
$7 \%$ in peptone-substituted culture medium (Figure 5). The flocculation activities of Bacillus cereus in ammonium and urea -substituted culture were the lowest. There were no significant differences in the effect of nitrogen sources on the isolate activities $(\mathrm{P}=0.74)$.

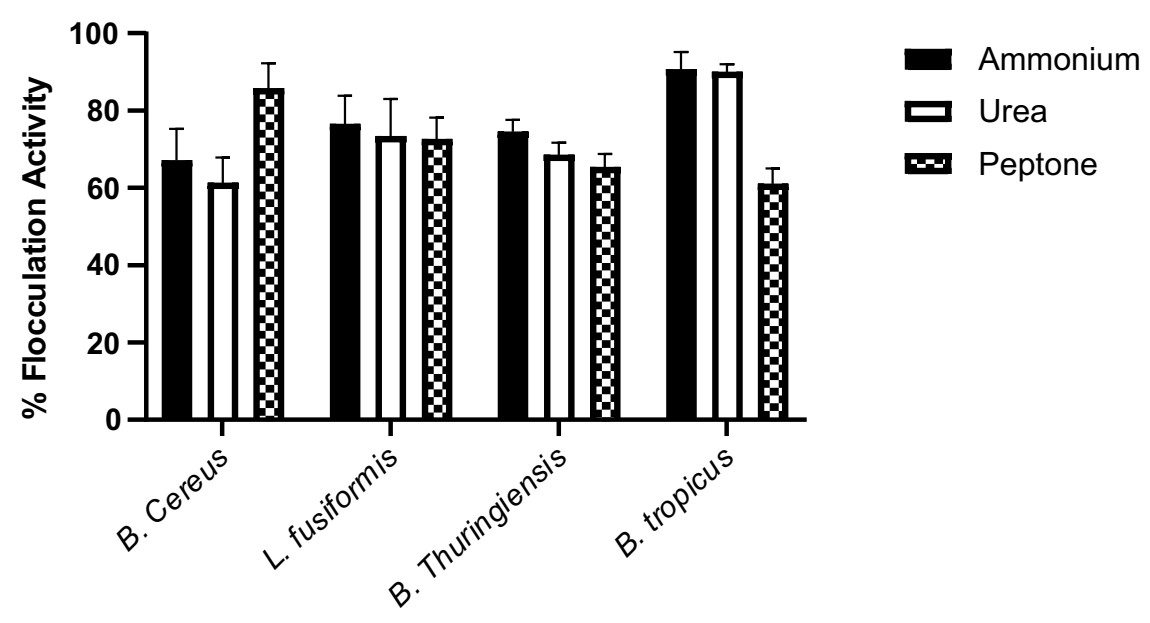

Figure 5: Average Percentage Flocculation Activities of Bacteria Isolates based on Nitrogen Sources

Effect of Hydraulic Conditions on Percentage Flocculation Activities

The flocculation activities of the bacterial isolates varied based on changes in hydraulic conditions (Figure 6). Bacillus thuringiensis exhibited the highest flocculation activities with condition III
$(86 \pm 2 \%)$ followed by condition I $(80 \pm 5 \%)$. The least affected isolate based on changes in hydraulic condition was Lysinibacillus fusiformis followed by Bacillus tropicus. There were no significant differences in the changes in hydraulic conditions on the isolate activities $(\mathrm{P}=0.19)$. 


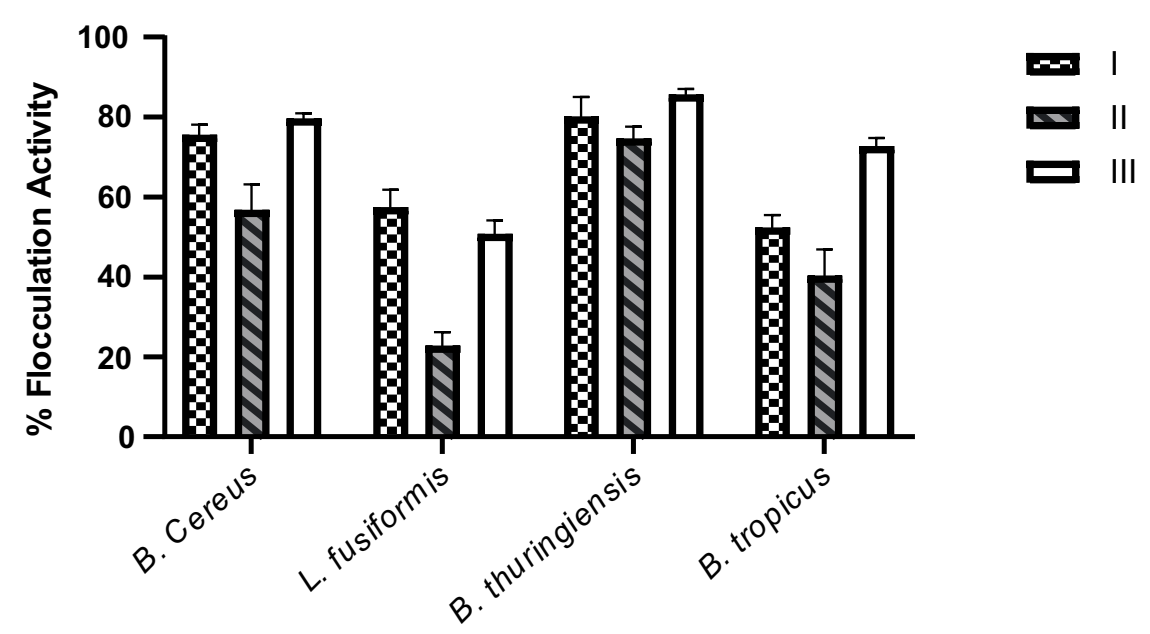

Figure 6: Average Percentage Flocculation Activities of Bacteria Isolates based on changes in Hydraulic Conditions

\section{DISCUSSION}

Bacillus cereus with soluble starch as the carbon source and Bacillus tropicus with maltose enriched media in this study showed the optimum flocculating activities of $98 \%$ at the following conditions: temperature $30{ }^{\circ} \mathrm{C}$, neutral $\mathrm{pH}$ and $\mathrm{CaCl}_{2}$ salt inclusion. Busi et al., (2017) and Akinola and Adebayo (2018) had reported $83.4 \%$ and $63.1 \%$ flocculating activity, respectively by Bacillus cereus bioflocculant. Although there has been no report of B. tropicus as a bioflocculation producing isolate, Liu et al. (2017) had grouped it as one of the species under the B. cereus group. This could be why they equally exhibited the same percentage flocculating activities as B. cereus in this study. Also, L. fusiformis was earlier reported as bioflocculantproducing bacteria (Pathak et al., 2014, 2017; Reubah et al., 2018).

The bioflocculating activities of B. thuringiensis of $84 \%$ with fructose as the carbon source and $85.6 \%$ under hydraulic condition III were the findings from this study which is not up to the activity of $93.8 \%$ reported in previous studies with $B$. thuringiensis (Wu et al., 2017). The higher performance may have resulted from the beef extract peptone medium used in their study. Beef extract is reported as the best nitrogen source for Bacillus subtilis in bioflocculation activities (Zhou et al., 2017), however, our study did not include beef extract as a substitute for nitrogen source.

The four bioflocculant producing isolates, Bacillus cereus and Lysinibacillus fusiformis (from oil polluted soil); Bacillus thuringiensis and Bacillus tropicus (from fermented maize waste water) from this study are from the Bacillaceae family. Three of them (Bacillus cereus, Bacillus thuringiensis and Bacillus tropicus) are from the genus Bacillus and the other (Lysinibacillus fusiformis) from the genus Lysinibacillus. Species of the genus Bacillus are the commonest bacteria known to secrete biopolymer flocculants (Suh et al., 1997; Salehizadeh and Shojaosadati, 2001; Deng et al., 2003). This is consistent with the findings of this study with $75 \%$ bioflocculant- producing isolates being of the genus Bacillus.

\section{CONCLUSION}

This study indicates that the best conditions for bioflocculant production by Bacillus cereus, Bacillus thuringiensis and Bacillus tropicus are neutral $\mathrm{pH}$, temperature of $30{ }^{\circ} \mathrm{C}$ with inclusion of $\mathrm{CaCl}_{2}$ salt and ditto for Lysinibacillus fusiformis except for the low $\mathrm{pH}$ condition. Maltose as the substituted carbon source was the best for all isolates except Bacillus thuringiensis (fructose) and B. Cereus (soluble starch). Ammonium was the best nitrogen source for all isolates except Bacillus cereus (peptone). Although condition III $(40 \mathrm{rpm} / 280 \mathrm{~s}$ then 160 $\mathrm{rpm} / 280 \mathrm{~s}$ ) was the optimum condition for flocculation activities for all isolates except Lysinibacillus fusiformis, the changes in conditions were not significantly different. Since Bacillus cereus and Bacillus tropicus showed highest percentage flocculating activities of $98 \%$, they can be exploited as a biofriendly replacement for chemical flocculants used in the treatment of 
Ogunlaja et al.: Optimization of Bioflocculant Production By Bacteria Isolated from Oil-Polluted Soil

water.

\section{REFERENCES}

Abd-El-Haleem, D. A., Al-Thani, R. F., AlMokemy, T., Al-Marii, S., and Hassan, F. 2008. Isolation and characterization of extracellular bioflocculants produced by bacteria isolated from Qatari ecosystems. Polish Journal of Microbiology, 57(3): 231239.

Akinola, O. and Adebayo, E. A. 2018. Screening and characterization of bioflocculantproducing bacteria isolated from domestic waste water in Bowen University, Iwo, Osun State, Nigeria. Nigerian Journal of Biotechnology, 35 (2): 159-166.

Busi, S., Karuganti, S., Rajkumari, J., Paramanandham, P. and Pattnaik, S. 2017. Sludge settling and algal flocculating activity of extracellular polymeric substance (EPS) derived from bacillus cereus SK. Water and Environment Journal, 31(1): 97-104.

Deng, S., Bai, R., Hu, X. and Luo, Q. 2003. Characteristics of a bioflocculant produced by Bacillus mucilaginosus and its use in starch wastewater treatment. Applied Microbiology and Biotechnology, 60 (5): 588-593.

Gao, J., Bao, H. Y., Xin, M. X., Liu, Y. X., Li, Q. and Zhang, Y. F. 2006. Characterization of a bioflocculant from a newly isolated Vagococcus sp. W31. Journal of Zhejiang University Science B, 7 (3): 186-192.

Gbaruko, B. C., Ana, G. R. E. E. and Nwachukwu, J. K. 2008. Ecotoxicology of arsenic in the hydrosphere: Implications for public health. African Journal of Biotechnology, 7 (25): $4734-4742$

Huang, X., Bo, X., Zhao, Y., Gao, B., Wang, Y., Sun, S., ... and Li, Q. 2014. Effects of compound bioflocculant on coagulation performance and floc properties for dye removal. Bioresource Technology, 165: 116121.

Lane, D.J. 1991. 16S/23S rRNA sequencing In: Stackebrandt E, Goodfellow M, editors. Nucleic acid techniques in bacterial systematics.

Liu, Y., Du, J., Lai, Q., Zeng, R., Ye, D., Xu, J. and Shao, Z. 2017. Proposal of nine novel species of the Bacillus cereus group. International Journal of Systematic and Evolutionary Microbiology, 67 (8): 2499-2508.

Madden T. 2013. The BLAST sequence analysis tool. In The NCBI Handbook [Internet]. 2nd edition 2013 Mar 15. National Center for Biotechnology Information (US).

Pathak, M., Devi, A., Sarma, H. K. and Lal, B. 2014. Application of bioflocculating property of Pseudomonas aeruginosa strain IASST201 in treatment of oil-field formation water. Journal of Basic Microbiology, 54 (7): 658-669.

Pathak, M., Sarma, H. K., Bhattacharyya, K. G., Subudhi, S., Bisht, V., Lal, B. and Devi, A. 2017. Characterization of a novel polymeric bioflocculant produced from bacterial utilization of $\mathrm{n}$-hexadecane and its application in removal of heavy metals. Frontiers in Microbiology, 8: 170.

Polizzi, S., Pira, E., Ferrara, M., Bugiani, M., Papaleo, A., Albera, R. and Palmi, S. 2002. Neurotoxic effects of aluminium among foundry workers and Alzheimer's disease. Neurotoxicology, 23 (6): 761-774.

Reubah. F.B., Mnif, W. and Siddeeg, M. S. 2018. Microbial flocculants as an alternative to synthetic polymers for wastewater treatment: a review. Symmetry, 10(11): 556.

Salehizadeh, H. and Shojaosadati S.A. 2001 Extracellular biopolymeric flocculants Recent trends and biotechnological importance. Biotechnology Advances, 19: 371-385.

Seo, G. T., Lee, T. S., Moon, B. H., Choi, K. S., and Lee, H. D. 1997. Membrane separation activated sludge for residual organic removal in oil wastewater. Water Science and Technology, 36 (12): 275-282.

Shih, L., and Van, Y. T. 2001. The production of poly- ã-glutamic acid from microorganisms and its various applications. Bioresource Technology, 79 (3): 207-225.

Suh, H. H., Kwon, G. S., Lee, C. H., Kim, H. S., Oh, H. M. and Yoon, B. D. 1997. Characterization of bioflocculant produced by Bacillus sp. DP-152. Journal of Fermentation and Bioengineering, 84 (2): 108112.

Takagi, H. and Kadowaki, K. 1985. Flocculant 
Ogunlaja et al.: Optimization of Bioflocculant Production By Bacteria Isolated from Oil-Polluted Soil

production by Paecilomyces sp. Taxonomic studies and culture conditions for production. Agriculture Biological Chemistry, 49: 3153-3157

Wu, J., Wang, G., Li, Z., Yu, E., Xie, J. and Zheng, Z. 2017. Extraction of flocculants from a strain of Bacillus thuringiensis and analysis of their properties. Aquaculture and Fisheries, 2(4): 179-184.

Zaki, S. A., Elkady, M. F., Farag, S. and Abd-ElHaleem, D. 2013. Characterization and flocculation properties of a carbohydrate bioflocculant from a newly isolated
Bacillus velezensis 40B. Journal of Environmental Biology, 34 (1): 51.

Zhang, M., Tay, J.H., Qian, Y. and Gu, X.S. 1998. Coke plant wastewater treatment by fixed biofilm system for $\mathrm{COD}$ and $\mathrm{NH}_{3}-\mathrm{N}$ removal. Water Research, 32 (2): 519-527.

Zhou, Y., Yang, Z.H., Huang, J., Xu, R., Song, P.P., Zhang, Y.J., Li, J. and Aloun, M. 2017. Ni (II) removal from aqueous solution by biosorption and flocculation using microbial flocculant GA1. Research on Chemical Intermediates, 43(7):3939-59. 